\title{
Need-Based English for Science and Technology: A Study in Relation to Engineering
}

\author{
R.N. Khanal \\ Department of Engineering Science and Humanities, Pulchok Campus, IOE, TU, Nepal
}

\begin{abstract}
Engineering is one of the major fields of applied science without which no country can move forward in the present global context. The teaching/learning of engineering in Nepal is not possible without English at present. The present paper attempts to highlight the relevance of English language for teaching/learning engineering in Nepal, It also attempts to indicate the relevance of the language for engineers to work in their respective fields. The focus of the paper is to suggest planners and teachers to select the need-based English, for the specific engineering purposes in the present world of specialization.
\end{abstract}

\section{Introduction}

The teaching/learning of English in Nepal starts from the early Rana Regime closely connected to the British Rule is India. In spike of several disturbances in the Nepalese system of education due to it, Nepal has been in touch with the most popular international language in the present world context. This language today has become essential for Nepalese people due to a number of reasons. The country cannot provide higher education without this language nor can it run schools and colleges with a view to teaching science and technology. The teaching of applied science like engineering is impossible without it.

No country can remain away from the rapid advancement in science and technology, That affects the existing system of education including the methods of language teaching/learning.

In spite of several attempts towards improving the teaching of English from the 1960's, no satisfactory results have yet been achieved. The teaching of this language has obviously got to be effective and efficient in the present age of science and technology.

Attempts have been made in this paper to highlight the importance of English in Nepal specially for teaching/learning engineering skills and ideas. Teachers need to encourage the pupils to make the maximum use of the language for the engineering purposes. As far as possible, recent and current ways and views concerning teaching English as a foreign language have been used while preparing the paper. The techniques of planning foreign language curriculum have also been considered. The paper is also based on the collective suggestions of the teachers, students and engineering experts concerned. In a sense, the emphasis of the paper is on the use of the need-based English for the engineering students from their time of the study at present up to their engineering career in future. Only than, it is expected, the teaching of this language can be guide 
to them during their whole engineering career. The paper deals with 1) Theoretical Basis for Language Teaching 2) The Concept of Need-Based English, and 3) English for Engineering

\section{Theoretical Basis for Language Teaching}

Without studying and considering the available recent and current views about language, language learning and language teaching, it is not possible to make an attempt to study and evaluate language teaching/learning at educational fields. Although language teachers are practical persons less connected with theories, they cannot remain away from "... the thought underlying language teaching"1, the, broader implication of the term "theory." Any effort in language teaching/learning procedures will be connected with the broad concept of linguistics as the term language teaching is interwovan with three factors: language, language learning and language teaching.

\section{a. Language}

The term "language" is a very complex phenomenon and it has not yet been confined within a single consistent and comprehensive theory. Different experts have defined it differently. But as indicated by S.Pit Corder, no definition of language can be disregarded in a language teaching program for its success to a desired extent.. Although it is a complex system of systems with several levels of complexity, a child masters it in the early age. A number of different theories of language teaching/learning follow this success of the child.

\section{b. Language Learning}

Language learning is basically a psychological problem but we know very little of the psychological of learning. It has not yet attained the scientific stage.

Structural linguists following behavioral psychology revolutionized foreign language teaching with the development of audio-lingual method or fundamental-skills method to supplant traditional grammar-translation method. With the advert of the generative transformation grammer this method has come under severe criticisms. The cognitive code-learning theory which is based on Gestalt psychology and transformational linguistics has questioned it in a number of ways. Linguists including Mueller suggest language teachers to reconcile all these views in order to achieve better results.

\section{c. Language Teaching}

As stated by Stern, language teaching is a group of activities planned with a view to bring about learning to a. maximum extent and the term primarily includes two factors- method and technique. Teaching of a language is largely determined by the method on which the program is based a language teaching method is "an overall plan for the orderly presentation of language material ... based upon the selected approach"2

Language teaching technique on the other hand is the implementation of the method adopted and hence it depends basically on the teacher and his/her teaching technology along with several other relevant factors.

\section{The Concept of Need-Based English}


The rapidity and recurrence of international communication have been challenging several fields of science and technology. The present world needs more and more specialization to cope with the rapid advancement in science and technology,

As a foreign language like English in Nepal is learned for a number of reasons, the nature of English course should vary according to the specific purposes of the learners. The teaching of English therefore must be specified according to the specific needs of the learners.

The modern development in ESP (English for specific purposes) concept has helped language experts to identify the purpose-specific area of English and they have been successful in identifying the special characteristics of the target language. It is difficult to define the term ESP mainly because the ESP movement from its beginning in 1960's has undergone different phases of development and has again emerged as a most popular approach in the field of language teaching to serve an increasing need for specialization For more than two decades educational linguists emphasized on the learner-centered language teaching programs, different from the traditional ones.

Till the 1970's the focus of the ESP approach was on the development of a language-centered curriculum. It lacked sound principles on language learning even if it attempted to focus on the specific language needs. Only from 1980's it started paying attention towards the process of learning.

From 1983 with the publications of writers such as Altman and Stern, the focus was shifted to the development of systematic and comprehensive procedures. These procedures contain similar components to those contained in the traditional procedures of curriculum development. But the procedures adopted in the

ESP approach are bottom-based whereas those of the traditional ones were placed on the hands of the curriculum specialists other than the teachers and learners concerned.

According to Tom Hutchinson and Alan Waters (1987), ESP approach is the modern approach to language learning and in this approach the decision regarding content and methodology of teaching is based on the learner's needs. This approach has steadily advanced and now it has been regarded as a need-based approach in language teaching/learning process. This approach has been applied largely on teaching English as a foreign language to profession-oriented learners like engineers. It emphasizes in developing courses relevant to the needs and interests of the learners with a view to enhancing their motivation in learning,

Besides gaining its special status in the field of teaching/learning English as a foreign language, ESP has been useful in making researches in a number of fields including needs-analysis curriculum designing, teacher-preparation and methods of teaching in all sectors of teaching /learning.

\section{English for Engineering}

The need and relevance of English in the institutes of science and technology in Nepal is very high. The field of engineering cannot be an exception to this fact. All the subjects in engineering curriculum require English and therefore engineering students need to have sound background of it.

The majority of the students of engineering in Nepal are aware of the need for improving English for their academic as well as professional purposes. They see little relevance of the existing compulsory English courses offered to them. The idea of a compulsory English course is also 
being unimportant. The students need to learn English for their specific purposes rather than to study English as a compulsory subject. The whole college education is heavily based on English and the students have got an ever-growing need for learning English in order to enhance their engineering studies.

The use of English in the field has to be ESP for science and Technology i.e. EST (English for science and Technology) based on their specific needs. EST is a very popular movement today. The process of assessing needs must be a continuous and open-ended process mainly because needs of the learners keep on changing. As far as practicable, the need-based EST approach (i.e. NEST) should be further developed into an EEP (English for engineering purposes) approach. Attempts must be made in separating one brand of EEP from the other depending upon the nature of the Engineering fields.

\section{Conclusion}

Mere efforts of teaching language without practical and down to earth consideration cannot be effective and efficient to a satisfactory measure. Educationists in Nepal have to realize this before attempting to plan language teaching.

At present the teaching of English at the institutes of engineering in Nepal has almost been an extra burden to the learners. The students require to learn the skills of engineering communication using this language rather than studying English as a subject.

\section{Suggestions/ Recommendations}

Attempts have to be made to update and improve the existing English language teaching curriculum with a view to converting it into a real engineering communication course. The existing situation of this language teaching should also be improved with the improvement in areas such as teacher-preparation and resources with proper and adequate language clinics. It is desirable to encourage the learners towards language use, communication technique and individual skill development. The researchers in the language teaching/learning fields have to be consulted properly.

\section{REFERENCES}

[1] Brasnett, Clive (1976): English for Engineers. London: Metheun Educational

[2] Candlin, Christopher N. (1986): Language Learning Tasks. London: Prentice Hall International (ELT)

[3] Hutchinson, Tom and Waters, Alan (1987): English for Specific Purposes : A Learning Centered Approach , Cambridge : CUP

[4] Mackey, W.F. (1976): Language Teaching Analysis. London: Longman

[5] Malla, K.P. (1977): English in Nepalese Education, Kathmandu: RP 13handar

[6] Mc. Donough, Jo (1984): ESP in perspective: A Practical Guide. London: Collins ELT

[7] Nunan, David (1988): The Le arner-C entered Curriculum. Cambridge: CUP

[8] Peck, Antony (1988): Language Teaching at Work: A Description of Methods, New York: Prentice Hall ELT

[9] Richard, Jack C. (1990): The Language Teaching Matrix. Cambridge-, CUP 
[10] Stern, H.H. (1984): Fundamental Concepts of Language Teching. London/New York: OUP

[11] Stubbs, Michael (1988): Educational Linguistics. Oxford: Basil Blackwell 